\title{
FORMATION OF LIGHT IMPURITIES IN A HYDROGEN PLASMA AT INITIAL STAGE OF A DISCHARGE
}

\author{
V.B. Yuferov, E.I. Skibenko, V.I. Tkachov, V.V. Katrechko, A.S. Svichkar \\ National Science Center "Kharkov Institute of Physics and Technology", Kharkiv, Ukraine \\ E-mail: v.yuferov@kipt.kharkov.ua
}

Analyzing the dynamics of density for atomic and molecular hydrogen ions, the values of atomic hydrogen and UV radiation fluxes to the walls of the plasma chamber were obtained, resulting in light impurities of carbon and oxygen at plasma start-up during the process of desorption from the walls under irradiation. The fluxes of impurity atoms associated with the fluxes of photons and hydrogen atoms in a discharge are determined. Recommendations are given to reduce the amount of impurities at the initial stage of discharge.

PACS: 52.50.Qt, 52.55.Hc

When considering the dynamics of the density of hydrogen atomic and molecular ions [1], the fluxes of atomic hydrogen and UV radiation on the walls of the plasma chamber were obtained. In the general case, at the initial stage of discharge, the flow of impurities into the plasma $F_{z}$ determined by the sum of the products of various radiation fluxes $F_{i}$, falling on the wall, by the value of the erosion coefficient for this type of radiation $\mathrm{K}_{i}: F_{Z}=\sum_{i} \kappa_{i} F_{i}$.
In this case, we consider the entry of light impurities through two processes: the supply of atomic hydrogen and UV radiation on the wall. As can be seen from the values of the effective cross sections of the processes, the formation of atomic hydrogen is especially effective for small $T_{e}$, wherein the number of atoms in the electron-ion pair for the $T_{e}$ (Fig. 1) defined as

$$
\frac{d F_{h}}{d n_{e}}=\frac{2 n_{2} \sigma_{3}+n_{2}^{+}\left(\sigma_{4}+2 \sigma_{6}\right)+n_{3}^{+}\left(2 \sigma_{9}+3 \sigma_{10}\right)+n_{2} n_{2}^{+} \sigma_{8} / n_{e}}{n_{2} \sigma_{1}+n_{2}^{+} \sigma_{4}+n_{1} \sigma_{7} n_{3}^{+} \sigma_{9}} .
$$

And as the electron plasma temperature changes from 4 to $12 \mathrm{eV}$, the number of generated hydrogen atoms drops from $\sim 18$ to $\sim 2$ atoms (Fig. 1). The time dependence of the averaged density of oxygen and carbon impurities for two values of the desorption coefficient and the electron temperature $\sim 6 \mathrm{eV}$ is shown in Fig. 2

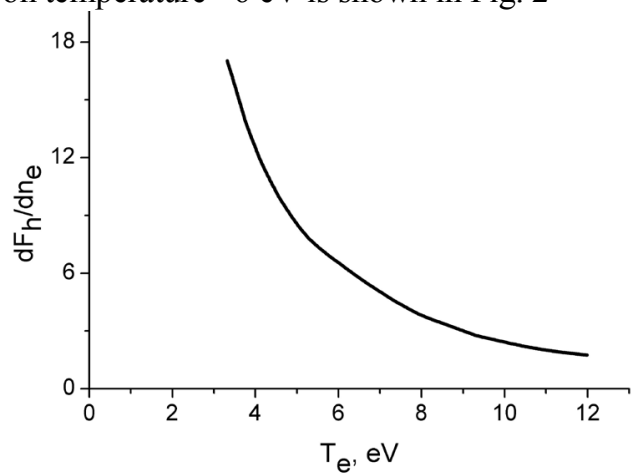

Fig. 1. Dependence of the number of hydrogen atoms per electron-ion pair on the temperature of electrons at plasma density $1 \cdot 10^{12} \mathrm{~cm}^{-3}$

$$
\begin{gathered}
\frac{d F_{p h}}{d t}=n_{e}\left[n_{1}\langle\sigma v\rangle_{L \alpha}+n_{2}\langle\sigma v\rangle_{H \alpha}+n_{2}^{+}\langle\sigma v\rangle_{L \alpha}\right]+ \\
+n_{Z}\langle\sigma v\rangle_{Z}=d F_{p h}^{10}+d F_{p h}^{5}+d F_{p h}^{3} ; \\
\frac{d n^{O}}{d t}=K_{p h}^{O} \frac{d F_{p h}}{d t}+K_{h}^{O} \frac{d F_{h}}{d t} ; \\
\frac{d n^{C}}{d t}=K_{p h}^{C} \frac{d F_{p h}}{d t}+K_{h}^{C} \frac{d F_{h}}{d t} ; \\
n_{1}+n_{2}+n_{3}+n^{C}+n^{O}-n_{e}=0 .
\end{gathered}
$$

In Fig. 2 show the time dependencies of the values $n^{c}$ and $n^{o}$ for $T_{e}=6 \mathrm{eV}$, we have chosen, for the reason that the time of generating plasma satisfy the conditions set in [2] $(0.5 \ldots 1 \mathrm{~ms})$.

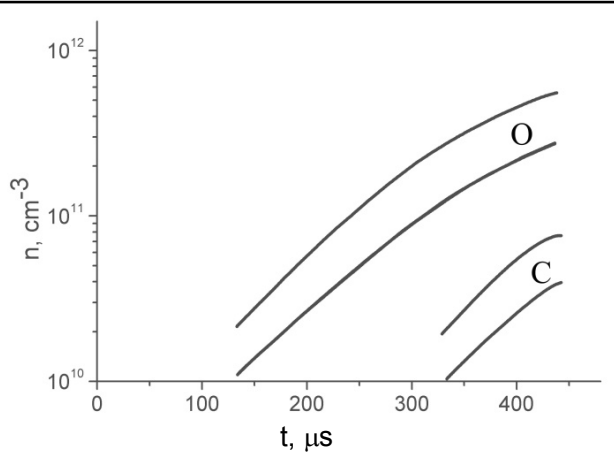

Fig. 2. Time dependence of the average density of oxygen and carbon impurities for two values of the desorption coefficient and the electron temperature $\sim 6 \mathrm{eV}$. For oxygen $1 \cdot 10^{-3}$ and $2 \cdot 10^{-3}$; carbon $-1 \cdot 10^{-2}$ and $2.5 \cdot 10^{-2}$

\section{SURFACE CONDITIONS THE AND THE SELECTION OF EROSION RATIO}

Selection of plausible desorption coefficient values $K_{p h}$ and $K_{h}$ is a very important operation, since their value significantly depends on the composition of the surface of the discharge chamber, which, in turn, determines the flow of impurities into the plasma. There is an extensive literature on the values of the sputtering coefficients of various materials by different ions, but there are very few data in the area of interest to us. In [3] shows the dependence of the coefficient of oxygen excretion $K_{h}{ }^{\mathrm{o}}$ in the form of water vapor from the surface of stainless steel when hydrogen atoms with an energy of $0.2 \mathrm{eV}$ interact with it. For temperature range $100 \ldots 400^{\circ} \mathrm{C}$ the value lies within $3 \cdot 10^{-3} \ldots 0.2$. Since in this work there is no data on the values $K_{h}{ }^{\circ}$ for room temperature and surface oxygen concentration, magnitude $K_{x}^{\mathrm{o}}$ was obtained by extrapolation, and the desorption cross section was estimated for the relative concen- 
tration of oxygen on the surface $\theta=0.15$, selected on the basis of the data of [3 - 8] for similar experimental conditions. Thus, the value we take $K_{h}{ }^{\mathrm{o}}=1 \cdot 10^{-5}$ for $T=300 \mathrm{~K}$ and $\sigma_{x}{ }^{\circ}=6.6 \cdot 10^{-18} \mathrm{~cm}^{-2}$. The value of the cross section for chemical removal of carbon from the inconel surface at temperature $T=470 \mathrm{~K}$ for the heat fluxes of atomic hydrogen is given in [8] $\sigma_{h}{ }^{\circ}=2.3 \cdot 10^{-17} \mathrm{~cm}^{-2}$ for filling $0.05 \leq \theta \leq 0.4$. Extrapolation to room temperature gives $\sigma_{h}{ }^{c} \approx 1 \cdot 10^{-20} \mathrm{~cm}^{-2}-$ a value that is rather small and therefore not taken into account, although, as in the case of oxygen, $\sigma_{h}{ }^{c}$ may increase with increasing energy of hydrogen atoms $E_{H}$. The magnitudes of the photodesorption cross sections strongly depend on the energy of the quanta, are maximum in the region of ultraviolet and soft X-ray radiation and lie at level $10^{-17} \ldots 10^{-20} \mathrm{~cm}^{-2}$ [1]. The measured value $K_{p h}$ for $\mathrm{CO}_{2}$ for quanta with energy from 2 to $10 \mathrm{eV}$ varies from $1.5 \cdot 10^{-4}$ to $1 \cdot 10^{-2}$ [6]. In [9] for radiation with $\lambda_{\text {min }}=1300 \mathrm{~A}, K_{p h}=2.5 \cdot 10^{-2}$ (for $\mathrm{CO}$ ). It should be noted that during the irradiation of oxygen- and carbon-containing surfaces simultaneously with electromagnetic (ultraviolet) radiation and atomic hydrogen, the yield of carbon and oxygen from the surfaces may increase. This, in our opinion, is due to the fact that intermediate products of chemical reactions are radicals $\mathrm{CH}, \mathrm{CH}_{2}, \mathrm{CH}_{3}, \mathrm{OH}$ on the surface can be desorbed by ultraviolet radiation, which will increase the coefficients of $K_{h}$ and $K_{p h}$. In the calculations, the $K_{p h}$ values are taken for quanta with an energy of 10.5 and $3 \mathrm{eV}$, respectively $1 \cdot 10^{-2}, 2 \cdot 10^{-2}$ and $1 \cdot 10^{-3}$.

The composition of the surfaces of the discharge chambers of thermonuclear installations, according to the data of [4 - 8], substantially depends on the working and cleaning conditions; immediately after purification with atomic hydrogen, the surface concentration of carbon, oxygen and sulfur lies at about $2 . .5 \%$ of each of the elements, respectively, the concentration of the substrate metal is about $85 \ldots 90 \%$. In the process of longterm operation, the composition of the surface can vary greatly in such a way that the concentration of carbon increases to $30 \ldots 95 \%$, oxygen to $10 \ldots 30 \%$, metal to $1 . . .35 \%$. (Unfortunately, the $K_{h}$ and $K_{h}^{o}$ values for films of this composition were not measured directly in the discharge chambers). In addition, in the intervals between the plasma pulses, i.e. peculiar cleaning, the surface composition may also change as a result of adsorption of water vapor, $\mathrm{CO}, \mathrm{CH}_{4}, \mathrm{CO}_{2}$, are always present in the discharge chamber and the divertor, and coming from the associated volumes. According to the data of $[10,11]$, we consider the composition of the atmosphere and the filling of the surface with oxygen $\theta$ in installations (Table 1).

\begin{tabular}{|c|c|c|c|c|}
\hline \multirow{5}{*}{$\begin{array}{l}\text { Atmospheric } \\
\text { composition }\end{array}$} & \multicolumn{4}{|c|}{ Partial pressure, $\mathrm{Pa}$} \\
\hline & \multicolumn{4}{|c|}{ Installations } \\
\hline & JET-2 & TFR-6 & & ASDEX \\
\hline & \multicolumn{4}{|c|}{ filling of the surface with oxygen } \\
\hline & No data & 0.02 & 1.0 & No data \\
\hline $\mathrm{HO}$ & $(2 \ldots 3.3) \cdot 10^{-5}$ & $1.3 \cdot 10^{-6}$ & $4 \cdot 10^{-6}$ & $6.7 \cdot 10^{-5}$ \\
\hline $\mathrm{CH}$ & $(1.3 \ldots 4) \cdot 10^{-6}$ & . & - & $2.7 \cdot 10^{-6}$ \\
\hline $\mathrm{CO}$ & $2.7 \cdot 10^{-6} \ldots 1 \cdot 10^{-5}$ & - & - & $1.4 \cdot 10^{-5}$ \\
\hline
\end{tabular}

It should be noted that in JET-2 and TFR-600 Special vacuum technologies for cleaning materials were used, including heating the chambers to $300 \ldots 400^{\circ} \mathrm{C}$, and in the case of TFR, a special initial heating of materials up to $800^{\circ} \mathrm{C}$ before installation of the system. Camera installation ASDEX could be heated only to $120^{\circ} \mathrm{C}$, in addition, its divertor was weakly purified during plasma purification. Therefore, in the period between plasma pulses, as mentioned above, a weakly coupled adsorption layer will increase on the cleaned surfaces of the discharge chambers, the concentration of which $n_{L}^{\text {surf }}$ will vary:

$$
n_{L}^{\text {surf }}=n_{L}^{\text {surf }}(0)+\text { const } \times A(\theta) \frac{A_{d s}}{A_{d c}} t p_{i} \times \delta^{-1},
$$

where $A(\theta)$ - coefficient of capture of particles in the discharge chamber; $A_{d s} / A_{d c}$ - the area ratio of the divertor slits and the discharge chamber; $\delta$-coefficient of surface roughness; $p_{i}$ - pressure in the diverter chamber. Coefficient $A(\theta)$ determined by the ratio $A_{d s} / A_{d \mathrm{c}}$ and the local coefficient of adhesion (capture) of gas on the surface $\alpha(\theta)$.

For most pure metals $\alpha(\theta)$ for room temperature, the substrates lie at a level of $0.1 \ldots 0.05$ for $\mathrm{CO}, \mathrm{CH}_{4}, \mathrm{CO}_{2}$; $0.5 \ldots 0.2$ for $\mathrm{H}_{2} \mathrm{O}$. For metal carbides, these values are about $0.5 \ldots 0.03$ [3]. Thus, in a wide range of variation of $\theta$, setting the pressure values $P_{i}$, characteristic of the case [2] (Table 2), and also taking into account the geometry of the system $A_{d s} / A_{d c}=5 \cdot 10^{-2}$ and $\delta=1$, at initial concentrations of oxygen and carbon on the surface, equal to $5 \%$, At initial concentrations of oxygen and carbon on the surface, equal to $n^{o}$ and $n^{c}$ for $\theta<0.2$ :

$$
\begin{aligned}
& n_{\text {surf }}^{O}=5 \times 10^{13}+3.9 \times 10^{12} \mathrm{t} ; \\
& n_{\text {surf }}^{C}=5 \times 10^{13}+2.9 \times 10^{12} \mathrm{t},
\end{aligned}
$$

where $\mathrm{t}-$ is the time of accumulation of impurities after cleaning the surface before filling with $\theta \approx 0.05$. As can be seen $K_{h}$ and $K_{p h}$ taken by us for fillings $\theta \approx 0.15$, will be achieved in a few tens of seconds, i.e. our choice is understated, since in the case of [2] the impulses usually go in $2 . . .3$ minutes.

\begin{tabular}{|c|c|c|c|c|}
\hline $\begin{array}{c}\text { Impurity } \\
\text { gases }\end{array}$ & $\mathrm{H}_{2} \mathrm{O}$ & $\mathrm{CO}$ & $\mathrm{CO}_{2}$ & $\mathrm{CH}_{4}$ \\
\hline Pressure, $\mathrm{Pa}$ & $1.33 \cdot 10^{-5}$ & $6.6 \cdot 10^{-6}$ & $4 \cdot 10^{-6}$ & $4 \cdot 10^{-6}$ \\
\hline
\end{tabular}

\section{CONCLUSIONS}

Thus, as can be seen from the results of the calculations in papers [1] and [3], the concentration of light impurities under equal conditions on the surface is determined by the temperature of the plasma electrons, which, in turn, affects the values of the fluxes $F_{h}$ and $F_{\text {eff }}$ and the ratios of the number of quanta or atoms on the ion-electron pair formed in the discharge, which change during the plasma generation process.

Reduced $T_{e}$ leads to an increase in income of impurities into the plasma by increasing the ratio of the number of photons and atoms in the ion-electron pair. Changes in temperature also leads to a redistribution contribution of photons and atoms in the impurity concentration. Moreover, at $T_{e}<6 \mathrm{eV}$ the contribution of $F_{h}$ is significant, at $T_{e}>6 \mathrm{eV}$ - are photons, since for the conditions under consideration $K_{p h}>>K_{h}$. 
It should also be noted that at the gas-kinetic rates of the desorbed molecules $\mathrm{H}_{2} \mathrm{O}, \mathrm{CH}_{2}$, $\mathrm{CO}$ the lengths before ionization at $n_{e}=10^{12} \ldots 10^{13} \mathrm{~cm}^{-3}$ lie in the range $10 \ldots 1 \mathrm{~cm}$. Moreover, as the density increases, the depth of penetration of impurities decreases. Here we do not consider elementary processes leading to a decrease in concentration gradients, nor processes of impurity transfer in plasma. Those at small $T_{e}$ impurities penetrate to a considerable depth, but still at $n_{e} \approx 1 \times 10^{13} \mathrm{~cm}^{-3}$ the capture of impurities goes to the outer plasma regions $\sim 1 \ldots 3 \mathrm{~cm}$. Such a distribution can be maintained long enough for small $T_{e}$ and $T_{i}$ due to very low values of the diffusion coefficients and large ionization rates. However, at the stage of plasma heating, due to an increase in the diffusion coefficients of the impurity for $1 \ldots 5 \mathrm{~ms}$ equalize radial distribution.

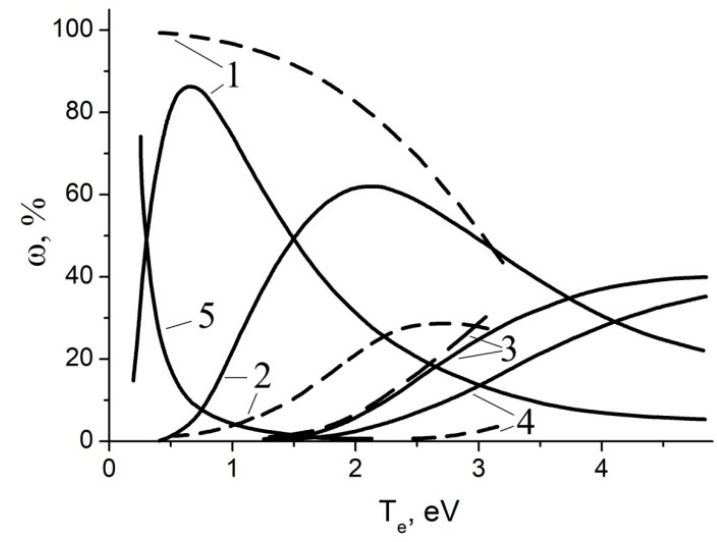

Fig. 3. Distribution of energy lost by electrons in $\mathrm{CO}_{2}$ (dashed line) and $\mathrm{H}_{2} \mathrm{O}$ (solid line) through various excitation channels: 1 -Oscillations; 2 -Electronic excitation (dissociation, dissociative adhesion); 3 -Electronic

excitation; 4 -Ionization; 5 -Elastic collision loss

It should also make some comments regarding the impurities. In Fig. 3 they are represented in the atomic state, whereas desorption from the surface occurs in the form of molecules, which in this case will be represented in the form of water molecules $\mathrm{H}_{2} \mathrm{O}$ and hydrocarbons, i.e. fragments of $\mathrm{C}_{n} \mathrm{H}_{m}$, in particular, methane $\mathrm{CH}_{4}, \mathrm{CH}_{3}$, $\mathrm{CH}, \mathrm{CO}_{2}$ clearly visible in the mass spectrograms plasma discharges. On the other side all these compounds have a radiating vibrational levels significantly increase the entrainment of the energy from the plasma.
In Fig. 3 shows the energetics of the vibrational levels for the $\mathrm{H}_{2} \mathrm{O}$ and $\mathrm{CO}_{2}$ molecules which indicates that in spite of the relatively small percentage of impurities $\mathrm{H}_{2} \mathrm{O}$ and $\mathrm{CO}_{2} \sim 10 \%$ in the hydrogen plasma, they will significantly increase the energy consumption of such hydrogen plasma discharges.

\section{REFERENCES}

1. G.W. Fabel, S.M. Cox, D. Lichtman. Photodesorption from 304 stainless steel // Surf. Sci. 1973, v. 40, p. 571.

2. E.D. Volkov, A.V. Georgievskij, A.G. Dikij, et al. Basic physical installation tasks "Uragan-3": Preprint KIPT 81-45. Kharhiv: KIPT AS USSR, 1981, $28 \mathrm{p}$.

3. G.M. Cracken, P.E. Stott. Plasma-surface interactions in tokamaks. Preprint CLM. Culham Laboratory, Oxfordshire, Abingdon, 1979, p. 573.

4. Desorption and related phenomena relevant to fusion device. JPPJ-AM-22. Nagaya, Japan, 1982, p. 101.

5. H.F. Dylla. A review of the wall problem and conditioning techniques for tokamaks // J. Nucl. Mat. 1980, v. 93/94, p. 61-74.

6. P. Staib, G. Staudenmaier. Surface effects and impurity production in tokamak machines // J. Nucl. Mat. 1978, v. 76/77, p. 78-91.

7. S.A. Cohen, H.F. Dylla, et al. Long-term changes in the surface conditions of PLT // J. Nucl. Mat. 1978, v. 76/77, p. 459-471.

8. J.V. Seggern, K.G. Tachersich. Dependence of inconel surface composition on the influx of hydrogen atoms // J. Nucl. Mat. 1978, v. 76/77. p. 600-604.

9. Yu.M. Pustovoit, V.N. Stolyarov. Unsprayable getters for fusion devices // Reports of the Second AllUnion Conference on the Engineering Problems of Thermonuclear Reactors. Leningrad, NIIEFA, 1982, iss. 4 , p. 53.

10. T. Hiraycima et al. On the origin of gaseous impurities measured by mass spectroscopy in the JET-2 tokamak // J. Nucl. Mat. 1978, v. 76/77, p. 587-593.

11. TFR Group (presented by P. Deschamps). Surface conditioning and mass spectroscopy in the TFR-600 tokamak // J. Nucl. Mat. 1978, v. 76/77, p. 587-593.

Article received 29.05.2019

\section{ОБРАЗОВАНИЕ ЛЕГКИХ ПРИМЕСЕЙ НА НАЧАЛЬНОЙ СТАДИИ РАЗРЯДА В.Б. Юферов, Е.И. Скибенко, В.И. Ткачев, В.В. Катречко, А.С. Свичкарь}

При рассмотрении динамики плотности водородных атомарных и молекулярных ионов получены величины потоков атомарного водорода и УФ-излучения на стенки плазменной камеры, в результате чего появляются легкие примеси углерода и кислорода на начальной стадии развития разряда в процессе десорбции со стенок при облучении. Определены величины потоков примесных атомов, связанных с потоками фотонов и атомов водорода, возникающих в разряде. Даны рекомендации по уменьшению количества примесей на начальной стадии разряда.

\section{УТВОРЕННЯ ЛЕГКИХ ДОМІШОК НА ПОЧАТКОВІЙ СТАДІЇ РОЗРЯДУ \\ В.Б. Юферов, С.І. Скібенко, В.І. Ткачов, В.В. Катречко, О.С. Свічкар}

При розгляді динаміки щільності водневих атомарних і молекулярних іонів отримані величини потоків атомарного водню і УФ-випромінювання на стінки плазмової камери, через що з'являються легкі домішки вуглецю і кисню на початковій стадії розряду в процесі десорбції зі стінок при опроміненні. Визначено величини потоків домішкових атомів, пов'язаних з потоками фотонів і атомів водню, що виникають у розряді. Надано рекомендації щодо зменшення кількості домішок на початковій стадії розряду. 